ström, J Brovall, J Torssander (South Hospital, Stockholm); G Norkrans (East Hospital, Gothenburg), C Håkansson (Sahlgren's Hospital, Gothenburg), B Christensson, B Ljungberg (Lund University Hospital).

Manuscript was prepared by: P C Gøtzsche in collaboration with $\mathrm{H}$ Melander, S R Norrby, P Andersen, J N Bruun, O Berglund, and P Skinhøj.

1 Mitsuya $\mathrm{H}$, Weinhold KJ, Furman PA, Clair MHS, Lehrman SN, Gallo RC et al. 3'-Azido-3'-deoxythymidine (BW A509U): an antiviral agent that inhibits the infectivity and cytopathic effect of human T-lymphotropic virus type III/lymphadenopathy-associated virus in vitro. Proc Natl Acad Sc US A 1985;82:7096-100.

2 Fischl MA, Richman DD, Grieco MH, Gottlieb MS, Volberding PA, Laski $\mathrm{OL}$, et al. The efficacy of azidothymidine (AZT) in the treatment of patient with AIDS and AIDS-related complex. A double-blind placebo-controlled trial. N Engl f Med 1987;317:185-91.

3 Dournon E, Matheron S, Rozenbaum W, Gharakhanian S, Michon C, Girard PM, et al. Effects of zidovudine in 365 consecutive patients with AIDS or PM, et al. Effects of zidovudine in 365 consecuive

4 Fischl MA, Richman DD, Causey DM, Grieco MH, Bryson Y, Mildvan D, $e t$ al. Prolonged zidovudine therapy in patients with AIDS and advanced AIDS-related complex. 7 AMA 1989;262:2405-10.

5 Richman DD, Fischl MA, Grieco MH, Gottlieb MS, Volberding PA, Laskin OL, et al. The toxicity of azidothymidine (AZT) in the treatment of patients with AIDS and AIDS-related complex. A double-blind placebo-controlled trial. N Engl f. Med 1987;317:192-7.

6 Revision of the CDC surveillance case definition for acquired immunodeficiency syndrome. MMWR 1987;36(suppl 1):1-15S

7 Karnofsky DA, Burchenal JH. The clinical evaluation of chemotherapeutic agents in cancer: In: Macleod CM, ed. Evaluation of chemotherapeutic agents.
Symposium held at New York Academy of Medicine, New York, 1948. New York: Columbia University Press, 1949:191-205.

8 Kalbfleisch JD, Prentice RL. The statistical analysis of failure time data. New York: Wilev, 1980 .

9 Phillips AN, Lee CA, Elford J, Janossy G, Timms A, Bofill M, et al. Serial CD4 lymphocyte counts and development of AIDS. Lancet 1991;337:389. 92.

10 Portegies P, Gans J, Lange JMA, Derix MMA, Speelman H, Bakker M, et al. Declining incidence of AIDS dementia complex after introduction of zidovudine treatment. BMF 1989;299:819-21.

11 Fischl MA, Parker CB, Pettinelli C, Wulfsohn M, Hirsch MS, Collier AC, et al. A randomized controlled trial of a reduced daily dose of zidovudine in patients with the acquired immunodeficiency syndrome. $N \mathrm{Engl}$ I Med 1990;323:1009-14

12 Volberding PA, Lagakos SW, Koch MA, Pettinelli C, Myers MW, Booth DK, et al. Zidovudine in asymptomatic human immunodeficiency virus infection. A controlled trial in persons with fewer than $500 \mathrm{CD}$ 4-positive cells per cubic millimeter. N Engl f Med 1990;322:941-9.

13 Pocock SJ. Clinical trials. A practical approach. Chichester: Wiley, 1983.

14 Gotzsche PC, Hvidberg EF, Juul P. Rational choice of dose: insufficient background knowledge? Ration Drug Ther 1986;20:1-7.

15 Yarchoan R, Klecker RW, Weinhold KJ, Markham PD, Lverly HK, Durack DT, et al. Administration of 3'-azido-3'-deoxythymidine, an inhibitor of HTLV-III/LAV replication, to patients with AIDS or AIDS-related HTLV-III/LAV replication,
complex. Lancet $1986 ; 1: 575-80$.

16 Larder BA, Darby G, Richman DD. HIV with reduced sensitivity to zidovudine (AZT) isolated during prolonged therapy. Science 1989;243: 1731-4

17 Boucher CAB, Tersmette M, Lange JMA, Kellam P, Goede REY, Mulder $\mathrm{JW}$, et al. Zidovudine sensitivity of human immunodeficiency viruses from high-risk, symptom-free individuals during therapy. Lancet 1990;336: 585-90.

(Accepted 16 October 1991)

\title{
Psychological aspects of lower urinary tract infections in women
}

\author{
David Sumners, Michael Kelsey, Ian Chait
}

Abstract

Objective-To determine whether women with the urethral syndrome can be distinguished from those with urinary tract infection by case notes, clinical symptoms, or psychiatric state.

Design-Longitudinal survey of consecutive women presenting with dysuria and frequency.

Setting-General practice and community.

Subjects -58 patients with the urethral syndrome and 44 patients with a urinary tract infection, mean age 39.9 years.

Main outcome measures-Results of analysis of serial midstream urine specimens, patients' self rated physical symptoms and responses to 60 item general health questionnaire at presentation and after resolution of symptoms, and results of psychiatric assessment with the clinical psychiatric interview.

Results -4 of 42 patients with a urinary tract infection had recently changed sexual partner compared with none of 58 with the urethral syndrome. Dysuria and nocturia were more common in patients with urinary tract infections than those with the urethral syndrome (mean (SD) score for dysuria 5.37 $(2.39) v 4.57(2.13), \mathrm{p}<0.05$; nocturia in $39 / 44(88 \%)$ patients $\left.v 40 / 58(69 \%), \chi^{2}=5 \cdot 5, \mathrm{p}<0.02\right)$. Both groups showed transient high levels of distress which resolved with the physical symptoms, but no psychiatric difference distinguished them.

Conclusion-The urethral syndrome is not associated with increased psychiatric morbidity.

Whittington Hospital London N19 5NF Michael Kelsey, FRCPATH, consultant microbiologist

Royal Free Hospital, London NW3 2QG Ian Chait, MRCGP, part time senior lecturer

Correspondence to:

Dr Sumners.

BMF 1992;304:17-9 defined as a pure growth of $\geqslant 10^{5}$ conventional urinary tract pathogens per $\mathrm{ml}$ of urine.

General practitioners might prescribe antibiotics more appropriately if they could predict significant bacteriuria before they had the midstream urine result. One study suggested that patients with the urethral syndrome exhibited less severe dysuria and their case notes were more likely to include "psychosomatic markers" such as anxiety, recurrent abdominal pain, and use of minor tranquillisers. ${ }^{6}$ We studied the psychiatric morbidity in women presenting with urinary tract disorders. We also examined other putative aetiological factors, including sexual and hygiene practices, as well as demographic characteristics.

\section{Subjects and methods}

General practitioners entered into the study all female patients aged 18 to 55 years presenting with dysuria and frequency over nine months. Exclusion criteria were pregnancy, complicated urinary tract disorder, receipt of antibiotics within 14 days, and insufficient command of English. A midstream urine specimen was obtained, co-trimoxazole prescribed, and the doctor predicted the result of analysis of the urine specimen.

The practice nurse completed an "aetiology schedule" by referring to the case notes and interviewing the patient. Information included demographic details; days elapsed since last period; degree of dysuria and frequency of micturition (both on seven point self rating scales); presence of nocturia; recent change of sexual partner; time since last sexual intercourse; number of sexual partners in the previous year; presence of an abnormal vaginal discharge; type of contraception used; preferences for bath or shower, tights or stockings, natural or synthetic underwear; and use of bath additives and biological or standard washing powder. The nurse determined the total number of consultations in the preceding two years for episodes of abdominal pain, anxiety, use of minor 
tranquillisers, and urinary frequency and dysuria.

Patients completed a 60 item general health questionnaire ${ }^{7}$ to screen for probable psychiatric morbidity. They were told that "a research doctor" might visit them at home. A one week follow up appointment was booked with the general practitioner to evaluate the outcome of treatment and to obtain a repeat midstream urine specimen.

All patients who scored 12 or more on the general health questionnaire were interviewed as well as a $50 \%$ sample of those scoring 11 or less, selected by using a table of random numbers. Patients with physical symptoms score high on the general health questionnaire, ${ }^{8}$ but this standard cut off point was retained to avoid missing true cases. The psychiatrist was blind to the questionnaire score and results of midstream urine analysis and assessed the patients at home with the clinical psychiatric interview. ${ }^{9}$ The interview is a standardised, semistructured instrument that enables a suitably trained psychiatrist to detect and diagnose psychiatric illness. It is not overtly psychiatric so that it is acceptable to psychologically normal individuals, and patients were unaware that the interviewer was a psychiatrist. All were left a second general health questionnaire to fill in three months later.

\section{STATISTICAL ANALYSIS}

We used $\chi^{2}$ tests to compare proportions of patients with specific features of the urethral syndrome and urinary tract infection and results of psychiatric assessments with those of midstream urine analysis. Fisher's exact test was used when the numbers were small and one of the boxes of the cross tabulation was zero. Normally distributed variables were compared with the $t$ test.

\section{Results}

Results of midstream urine analysis were obtained for 102 of the 106 patients entered into the study. Their mean age was 39.9 years, and 44 had a urinary tract infection. Bacteriuria was not related to marital condition, age, number of children, socioeconomic class, hygiene factors, previous history of frequency and dysuria, total number of previous consultations, or frequency of anxiety, recurrent abdominal pain, or use of minor tranquillisers.

TABLE I-Results of self rated questionnaire on nocturia, frequency, and dysuria

\begin{tabular}{lccc}
\hline & $\begin{array}{c}\text { Patients with urethral } \\
\text { syndrome } \\
(\mathrm{n}=58)\end{array}$ & $\begin{array}{c}\text { Patients with urinary } \\
\text { tract infection } \\
(\mathbf{n}=\mathbf{4 4})\end{array}$ & Significance \\
\hline No of patients with nocturia & 40 & 39 & $\chi^{2}=5 \cdot 5, \mathrm{df}=1, \mathrm{p}<0.02$ \\
Mean (SD) frequency score & $5 \cdot 7(1)$ & $5 \cdot 7(0 \cdot 48)$ & $\mathrm{NS}$ \\
Mean (SD) dysuria score & $4 \cdot 57(2 \cdot 13)$ & $5 \cdot 37(2 \cdot 39)$ & $t=1 \cdot 998 ; \mathrm{p}<0.05$ \\
\hline
\end{tabular}

TABLE II - Psychological characteristics in women with urethral syndrome and urinary tract infection

\begin{tabular}{|c|c|c|}
\hline & Urethral syndrome & Urinary tract infection \\
\hline \multicolumn{3}{|c|}{ First general health questionnaire: } \\
\hline No of patients & 58 & 44 \\
\hline No scoring $\geqslant 12$ & 28 & $18^{\star}$ \\
\hline \multicolumn{3}{|c|}{ Second general health questionnaire: } \\
\hline No of patients & 40 & 29 \\
\hline No scoring $\geqslant 12$ & 10 & 9 * \\
\hline \multicolumn{3}{|l|}{ Clinical psychiatric interview: } \\
\hline No of patients & 40 & 29 \\
\hline $\begin{array}{l}\text { No with psychiatric } \\
\text { disorder }\end{array}$ & 10 & $5 \star$ \\
\hline \multirow[t]{6}{*}{ Psychiatric diagnosis (ICD 9) } & $\begin{array}{l}296 \cdot 1 \text { Manic depressive psychosis } \\
\text { (depressed) }\end{array}$ & $\begin{array}{c}296 \cdot 1 \text { Manic depressive psychosis } \\
\text { (depressed) }\end{array}$ \\
\hline & $300 \cdot 2$ Phobic state & $300 \cdot 0$ Anxiety state \\
\hline & $\begin{array}{l}300 \cdot 4 \begin{array}{l}\text { Neurotic depression }(5 \\
\text { patients) }\end{array}\end{array}$ & $300 \cdot 4$ Neurotic depression \\
\hline & $301 \cdot 1$ Affective personality disorder & $309 \cdot 0$ Brief depressive reaction \\
\hline & $\begin{array}{l}301 \cdot 4 \text { Anankastic personality } \\
\text { disorder }\end{array}$ & 309-1 Prolonged depressive reaction \\
\hline & 309.1 Prolonged depressive reaction & \\
\hline
\end{tabular}

$\star=$ Not significant.
Four out of 42 respondents with a urinary tract infection had changed their sexual partner in the past month compared with none of 58 patients with the urethral syndrome $(p=0.03$, Fisher's exact test). Urinary tract infection was significantly associated with more nocturia and dysuria but not with frequency (table I). General practitioners correctly predicted the results of midstream urine analysis in three out of 58 patients with the urethral syndrome and 42 out of 44 patients with urinary tract infection.

The general health questionnaire classified 46 patients as having a probable psychiatric disorder and 56 as normal. The results of the questionnaire were not related to the results of midstream urine analysis: mean score 13.04 in patients with urinary tract infection, 13.2 in those with the urethral syndrome. Sixty nine patients who had been assessed with the clinical psychiatric interview completed a second general health questionnaire. Their scores were much lower and still showed no significant relation with bacteriuria (table II). The sensitivity (proportion of patients with psychiatric disorders correctly identified) of the general health questionnaire was $100 \%$ and the specificity (proportion of psychiatrically normal patients correctly identified) was $65 \%$ with this cut off score. Manipulation of the threshold to $16 / 17$ and 20/21 resulted in only marginal improvements in specificity $74 \%$ and $68 \%$ respectively) but a large drop in sensitivity $(60 \%$ and $38 \%$ respectively).

Five out of 29 patients with a positive initial midstream urine specimen and 10 out of 40 patients with a negative initial specimen had a psychiatric disease diagnosed (using ICD ninth revision) by the clinical psychiatric interview. This difference was not significant (table II).

We compared patients according to the results of midstream urine analysis. Those with pure growth of $\geqslant 10^{4}$ conventional urinary tract pathogens per $\mathrm{ml}$ were compared with those with mixed growth plus those with negative cultures, and those with negative cultures were compared with all other patients. None of these groupings produced any significant difference in psychiatric status.

\section{Discussion}

The aetiology of the urethral syndrome has been the subject of considerable debate. ${ }^{10}$ Increased sexual activity or "honeymoon" cystitis has been suggested as a factor, " but our results link only urinary tract infection with a change of sexual partner.

Studies in urology clinics suggested an emotional basis for the urethral syndrome, ${ }^{12-16}$ but patients were highly selected, there were no adequate controls, and in most studies objective measures of psychiatric morbidity were not used.

Our community based study used objective psychiatric measures and found no difference in morbidity between patients with the urethral syndrome and those with urinary tract infection. Women who experience dysuria and frequency are clearly distressed, which seems to result in the high initial scores on the general health questionnaire. The questionnaire can classify patients with physical problems as probable psychiatric cases, ${ }^{9}$ but high scores fall as the physical symptoms resolve, ${ }^{17}$ as seen in our patients.

We found that general practitioners could not predict the result of midstream urine analysis and generally diagnosed a urinary tract infection. This conforms with Brooks's findings that most patients with dysuria and frequency receive antibiotics. ${ }^{2}$ O'Dowd et al speculated that accurate prediction of bacteriuria resulted from balancing a clinical feature (dysuria) with other factors such as a history of anxiety. Our patients with a urinary tract infection also 
exhibited more dysuria, but the urethral syndrome was not associated with any increase in psychiatric morbidity.

When no infection is found doctors may be more likely to regard patients' emotions as the cause rather than the effect of the condition. ${ }^{18}$ Our findings indicate that patients with the urethral syndrome are no more neurotic than those with significant bacteriuria and that both groups require tolerance of the distress engendered by their conditions.

We wish to thank the practice nurses Jill Wood, Julie Ripper, and Trisha Crisp; Wellcome; and Dr Stuart Turner.

1 Fry J. Common diseases: their nature, incidence and care. Manchester: MTP Press, 1980.

2 Brooks D. A general practitioner's view of the laboratory examination of urine. In: Meers PD, ed. The bacteriological examination of urine: report of $a$ in: Meers $\mathrm{PD}$, ed. The bacteriological examination of urne: report of a workshop on needs and

3 Waters WE. Prevalence of symptoms of urinary tract infection in women. Br J Prev Soc Med 1969;23:293-6.

4 Gallagher DJA, Montgomerie JZ, North JDK. Acute infections of the urinary tract and the urethral syndrome in general practice. BMF 1965;i:622-6.
Report by members of the Medical Research Council Bacteriuria Committee. Recommended terminology of urinary tract infection. BM7 1979;ii:717-9.

6 O'Dowd TC, Smail JE, West RR. Clinical judgment in the diagnosis and management of frequency and dysuria in general practice. $B M \mathcal{F} 1984 ; 288$ : 208-12.

7 Goldberg DP. The detection of psychiatric illness by questionnaire. London: Oxford University Press, 1972 .

8 Finlay-Jones RA, Murphy E. Severity of psychiatric disorder and the 30 item general health questionnaire. Br f Psychiatry 1979;134:609-16.

Goldberg DP, Cooper B, Eastwood MR, Kedward HB, Shepherd $M$. A standardised psychiatric interview for use in community surveys. Brf Prev Soc Med 1970;24:18-26.

10 Brumfitt W, Hamilton-Miller HMT, Gillespie WA. The mysterious "urethral syndrome." BMF 1991;303:1-2.

1 Scotti RJ, Ostergard DR. The urethral syndrome. Clin Obstet Gynecol 1984;27:515-29.

12 Gray LA, Pingleton WB. Pathological lesions of the female urethra. $\mathcal{F A M A}$ 1956;162:1361-5.

13 Boreham P. Cryosurgery for the urethral syndrome. f R Soc Med 1984;77: $111-3$.

14 Schmidt RA. The urethral syndrome. Urol Clin North Am 1985;12:349-54

15 Mason E, McLean P, Cox J. Psychosocial aspects of the urethral syndrome in women. Fournal of the Irish Medical Association 1977;70:335-7.

6 Rees DLP, Farhoumand N. Psychiatric aspects of recurrent cystitis in women. Br f Urol 1977;49:651-8.

17 Frost D, Fitzpatrick R, Ikkos G. A survey of psychological disturbance in clinic for sexually transmitted diseases. Br $\mathcal{F}$ Psychiatry 1981;138:292-6.

18 Eisenberg J. Sociologic influences on decision making by clinicians. Ann Intern Med 1979;90:957-64

(Accepted 10 October 1991)

\section{Department of}

Ophthalmology,

Trondheim University

Hospital, N-7006

Trondheim, Norway

Olaf Brinchmann-Hansen

MD, professor

Aker University Hospital, Oslo

Knut Dahl-Jørgensen, MD, chief physician, Aker Diabetes Research Center

Kristian F Hanssen, MD, chief physician, department of medicine

Medstat Ltd, Oslo

Leiv Sandvik, BSC, medical statistician

Correspondence to:

Professor

Brinchmann-Hansen.

BMf 1992;304: 19-22

\title{
Blood glucose concentrations and progression of diabetic retinopathy: the seven year results of the Oslo study
}

\author{
Olaf Brinchmann-Hansen, Knut Dahl-Jørgensen, Leiv Sandvik, Kristian F Hanssen
}

\begin{abstract}
Objective-To study insulin dependent diabetic patients for change in non-proliferative retinopathy and its relation to glycaemic control and to various clinical background data.

Design-Prospective study with follow up for seven years.

Setting-Outpatient departments of university hospitals.

Main outcome measures-Glycated haemoglobin concentration; degree of retinopathy.

Results-Retinopathy worsened by an overall increase in counts of microaneurysms and haemorrhages from 17 (SD 25) to $45(58)(p=0.005)$. Intensified insulin treatment and home blood glucose monitoring improved concentrations of glycated haemoglobin $\left(\mathbf{H b A}_{1}\right)$ from $11 \cdot 2 \%(2 \cdot 2 \%)$ at the start of the study to a mean of $9.5 \%(1.5 \%)$ over the seven years of the study $(\mathbf{p}<\mathbf{0 . 0 0 0 1 )}$. A mean value for $\mathbf{H b A}_{1}>10 \%$ was associated with an increased risk of progression of retinopathy and a mean value $<8.7 \%$ was associated with a diminished risk. Multiple regression analysis identified four independent variables as indicative of outcome of retinopathy after seven years: $\mathrm{HbA}_{1}$ value at baseline; the change in $\mathbf{H b A}_{1}$ from start to the mean level through the seven years; duration of diabetes; and retinopathy at start. Age, blood pressure, and urinary albumin excretion were not related to the presence or progression of retinopathy.

Conclusion-Secondary intervention by long term lowering of glycated haemoglobin has a beneficial impact on non-proliferative retinopathy. A four factor regression model can determine patients at high risk of severe retinopathy.
\end{abstract}

\section{Introduction}

An accumulation of data suggests an association between hyperglycaemia and the incidence and progression of diabetic retinopathy. ${ }^{1-9}$ Intervention studies, in which attempts have been made to lower mean blood glucose levels give conflicting results regarding beneficial effects on progression of retinopathy ${ }^{10-20}$ - but they have all studied the patients for only a short period, up to three years.

The severity of retinopathy is related mainly to the duration of diabetes. Exposure to various factors in diabetes can be characterised by intensity, duration, and cumulative dose (intensity times duration). ${ }^{21}$ The results obtained in a well designed study may depend on a cumulative dose being reached through sufficient duration of the study. This is illustrated by our study, in which the same patients were examined by identical tests at intervals for seven years.

The Oslo study was originally designed as a prospective, randomised study of the effects of insulin pumps, multiple insulin injections, and conventional treatment with insulin..$^{22-27}$ Results after two years showed marginal beneficial effect of intervention on progression of retinopathy..$^{25}$ This effect was not evident after three to four years, ${ }^{26}$ even though assessment was performed according to both the mode of insulin treatment and the mean blood glucose concentration. After seven years' follow up, however, the long term beneficial effects of improved glycaemic control were evident. The present paper determines the change in retinopathy after seven years, examines relevant clinical variables, identifies four independent risk factors, and presents a long term regression model for severity of non-proliferative retinopathy.

\section{Patients and methods}

Forty five insulin dependent diabetic patients were included in the Oslo study seven years ago. Inclusion criteria and background clinical data have been described previously. ${ }^{22-27}$

Table I shows background data relevant to the current paper at the start of the study and after seven years. At baseline, the 21 men and 24 women averaged 26 (range 18-36) years and had had diabetes for 13 (6-23) years. They had no clinical signs of systemic hypertension, nephropathy, or neuropathy; 